\title{
Pendugaan Parameter Genetik Sifat Pertumbuhan Sapi Bali di BPTU HPT Denpasar
}

\author{
(Estimation of Genetic Parameters forGrowth Traits of Bali Cattle \\ in Breeding Centre of Bali Cattle)
}

R.J.W. Setiyabudi*, Muladno, R. Priyanto

\begin{abstract}
Department of Animal Production and Technology, Faculty of Animal Science, Bogor Agricultural University J1. Agatis, Kampus IPB Dramaga, Bogor 16680, Indonesia

*Corresponding Phone and E-mail: +62817 5423 992; radenjatu@gmail.com
\end{abstract}

\begin{abstract}
Breeding Center of Bali Cattle in Bali has applied Village Breeding Center (VBC) Program which an area of farmer belonging to groups that develop breeding program. These farms are expected to act as nuclei in open nucleus schemes, where superior animals are multiplied at Breeding Center (nucleus), distributed to farmers, andthe best animals from the farmers are brought back to the central farm for further breeding. This study was to estimate non-genetic and genetic of growth traits consisting of birth (BW), weaning (WW), and 12 months (YW) weight. This study used pedegree record of Breeding Center from 2008 to 2013 years. The number of sapi Bali used to determine growth traits of BW, WW, and YW were 573; 541; and 523 heads, respectively.Data were analyzed using General Linier Model (GLM) to identify non-genetic. Estimation of genetic including heritability, repeatability, genetic and phenotypic correlation were calculated using General Linier Model and Restricted Maximum Likelihood. Genetic and phenotypic trends were calculated using the regression mean breeding values on birth year.Heritability values were $0.02 \pm 0.08 ; 0.83 \pm 0.18$ and $0.62 \pm 0.30$ for $B W, W W$ and $Y W$, respectively. The higest correlation showed between $W W$ and $Y W$ for genetic and fenotipic were 0.719 and 0.650 , respectively. The regression estimates on various trends of EBV and phenotipic trends for WW and YW showed no definite trendsince the regression equation was not significant $(P>0.01)$ and $R^{2}$ was relatively low, but the phenotypic trends of $\mathrm{BW}$ showed constant decrease $(\mathrm{P}<0.01)$. The results obtained in the present study realized that one signaling to the programthat need for evaluated in selection and or management procedure in the scheme.
\end{abstract}

Keywords: VBC, Bali cattle, genetic parameters.

\section{PENDAHULUAN}

Bibit merupakan salah satu faktor produksi yang paling penting dalam usaha peternakan. Penyediaan bibit yang cukup dan berkualitas guna menunjang keberhasilan usaha peternakan akan meningkatkan efisiensi usaha sehingga dapat meningkatkan keuntungan dan daya produk peternakan. Pemerintah dan/atau Pemerintah Daerah sesuai dengan kewenangannya berkewajiban untuk melakukan pemuliaan, pengembangan usaha pembenihan dan/atau pembibitan dengan melibatkan peran serta masyarakat untuk menjamin ketersediaan Benih dan/atau Bibit (UndangUndang Nomor 41 Tahun 2014 pasal 13 ayat 1).

Program nasional untuk peningkatan mutu genetik ternak dengan melakukan seleksi dalam bangsa sehingga diperoleh bibit sapi Bali yang bermutu baik telah dilakukan sejak tahun 1976. Selanjutnya pada tahun 2007 pemerintah mendirikan Balai Pembibitan Ternak Unggul (BPTU) Sapi Bali, sekarang bernama Balai Pembibitan Ternak Unggul dan Hijauan Pakan Ternak (BPTU HPT) Denpasar, dalam rangka meningkatkan kinerja usaha pembibitan yang telah dilaksanakan dengan melaksanakan usaha pembibitan ternak rakyat yang kemudian disebut Village Breeding Center(VBC).

VBC adalah suatu kawasan pengembangan peternakan yang berbasis pada usaha pembibitan ternak rakyat yang tergabung dalam kelompok peternak pembibit (Peraturan Direktur Jenderal Peternakan Nomor 07007/HK.030/F/05/2008). Pemuliaan kolaboratif ini dikembangkan mempergunakan skema inti-terbuka (open nucleus breeding scheme) dimana terdapat aliran ternak dari populasi inti ke populasi plasma dan sebaliknya (Mueller 1984; Haris \& Newman 1994; Tada 2012). Pola pemuliaan ini mampu menurunkan tingkat inbreeding di populasi inti karena diversifikasi asal ternak (Mizeck et al., 2003; Assan 2012).Bagi plasma dengan adanya pola inti-plasma terbuka dapat mempercepat perbaikan genetik ternak yang dimiliki serta meningkatkan keterampilan dalam melakukan pemuliaan (Madalena et al., 2002; Assan 2012).

Peternak kelompok binaan diajarkan melaksanakan 
pemuliaan sederhana untuk memperoleh bibit/calon bibit ternak yang baik yang akan dijaring oleh inti berdasarkan ukuran fenotipik mengacu kepada Standar Nasional Indonesia (SNI) Sapi Bali (SNI 7355:2008). Program pemuliaaanmempergunakan skema VBC dimaksudkan untuk meningkatkan rataan penampilan populasi sapi Bali di pusat pembibitan di BPTU HPT Denpasar dan kelompok plasma/binaan.

Rataan fenotipik dan genetik sebagai hasil pemuliaan yang telah dilaksanakan selama ini perlu terus dimonitor dan dievaluasi tiap tahunnya. Tren genetik untuk sifat pertumbuhan sapi harus terus dimonitor untuk memeriksa validitas dari perhitungan yang dibuat dan untuk menyelidiki arah perubahan genetik. Tren genetik mencerminkan peningkatan mutu genetikpopulasi dari waktu ke waktu (Gunawan et al., 2012). Penelitian ini bertujuan untuk mengestimasi tren fenotipik dan genetik sapi Bali di BPTU HPT Denpasar Provinsi Bali.

\section{MATERI DAN METODE}

\section{Lokasi dan Waktu}

Penelitian ini dilaksanakan di Balai Pembibitan Ternak Unggul dan Hijauan Pakan Ternak (BPTU-HPT) Denpasar Bali dan Laboratorium Pemuliaan dan Genetika Ternak Fakultas Peternakan IPB pada bulan Oktober 2014 sampai Desember 2014.

\section{Materi}

Data yang digunakan pada penelitian ini merupakan hasil koleksi BPTU HPT Denpasar dari tahun 2008 - 2013. Data meliputi data non-genetik yaitu catatan jenis kelamin, paritas, dan tahun kelahiran serta data genetik yaitu catatan data bobot lahir (BL), sapih (BS), dan 12 bulan (BY) dengan jumlah ternak masing-masing 573, 541 dan 523 ekor.

Data bobot badan sebelum analisis dilakukan koreksi untuk bobot sapih umur 205 hari (WW205) dan bobot setahun/365 hari (YW365). Data bobot lahir sapi ada sehingga dipergunakan rumus koreksi menurut Beef Improvement Federation (2002) sebagai berikut :

WW205 $=\left\{\left[\frac{\text { Bobot Sapih }- \text { Bobot Lahir }}{\text { umur }}\right] \times 205\right.$ hari $\}+$ Bobot Lahir YW365 $=\left\{\left[\frac{\text { Bobot } 1 \text { Tahun }- \text { Bobot 205 hari }}{\text { umur }-205}\right] \times 160\right.$ hari $\}+$ Bobot 205 hari

\section{Pengaruh Genetik}

\section{Prosedur Analisis Data}

Analisis yang digunakan untuk mempelajari pengaruh genetik, pendugaan nilai parameter genetik dihitung melalui analisis mixed modelmenggunakan program R. Model analisis parameter genetik (heritabilitas, ripitabilitas dan korelasi genetik) yang digunakan disajikan sebagai berikut:

Pendugaan nilai heritabilitas dihitung dari komponen varian pejantan dan betina berdasarkan Becker (1992) disajikan sebagai berikut:

$$
\mathrm{h}_{\mathrm{s}}^{2}=\frac{4 \delta_{\mathrm{s}}^{2}}{\left(\delta_{\mathrm{s}}^{2}+\delta_{\mathrm{d}}^{2}+\delta_{\mathrm{w}}^{2}\right)}
$$

keterangan:

$\mathrm{h}_{\mathrm{d}}^{2} \mathrm{~h}_{\mathrm{d}}^{2}=$ heritabilitas dari komponen induk

$\delta_{\mathrm{S}}^{2} \delta_{\mathrm{S}}^{2} \quad=$ ragam pejantan

$\delta_{\mathrm{d}}^{2} \delta_{\mathrm{d}}^{2} \quad=$ ragam induk dalam pejantan

$\delta_{\mathrm{W}}^{2} \delta_{\mathrm{w}}^{2}=$ ragam dalam keturunan

Pendugaan nilai ripitabilitas dihitung dengan menggunakan rumus matematis berdasarkan Becker (1992) disajikan sebagai berikut:

$$
\mathrm{R}=\frac{\delta_{\mathrm{w}}^{2}}{\delta_{\mathrm{w}}^{2}+\delta_{\mathrm{e}}^{2}}
$$

$$
\delta_{\mathrm{e}}^{2}=\mathrm{MS}_{\mathrm{e}} \operatorname{dan} \delta_{\mathrm{w}}^{2}=\frac{\mathrm{MS}_{\mathrm{w}}-\mathrm{MS}_{\mathrm{e}}}{\mathrm{k}_{1}}
$$

keterangan:

$\delta_{\mathrm{W}}^{2} \delta_{\mathrm{W}}^{2}=$ ragam sifat antara individu-individu yang diamati $\delta_{\mathrm{e}}^{2} \delta_{\mathrm{e}}^{2} \quad=$ ragam sifat berdasarkan pengukuran-pengukuran dalam individu yang diamati

$\mathrm{MS}_{\mathrm{W}} \mathrm{MS}_{\mathrm{W}}=$ kuadrat tengah sifat yang diamati

$\mathrm{MS}_{\mathrm{e}} \mathrm{MS}_{\mathrm{e}}=$ kuadrat tengah individu yang diamati

$\mathrm{k}_{1} \mathrm{k}_{1} \quad=$ jumlah pencatatan atau ulangan

Pendugaan nilai korelasi genetik dan fenotipik dihitung dengan menggunakan rumus matematis berdasarkan Becker (1992) disajikan sebagai berikut:

$$
\begin{gathered}
r_{g}=\frac{\operatorname{cov}_{0}}{\sqrt{\delta_{o x}^{2} \delta_{e y}^{2}}} \\
r_{p}=\frac{\operatorname{cov}_{0}+\operatorname{cov}_{e}}{\sqrt{\left(\delta_{o x}^{2}+\delta_{e x}^{2}\right) \times\left(\delta_{o y}^{2}+\delta_{e y}^{2}\right)}}
\end{gathered}
$$

keterangan:

$$
\begin{array}{ll}
\operatorname{cov}_{g} \operatorname{cov} v_{g} & =\text { peragam komponen genetik } \\
\sigma_{g 1} \sigma_{g 1} & =\text { ragam komponen sifat pertama } \\
\sigma_{g 2} \sigma_{g 2} & =\text { ragam komponen sifat kedua }
\end{array}
$$

\section{Pengaruh Non-Genetik dan Genetik}

Untuk menilai pengaruh non genetik pada bobot lahir, bobot sapih, bobot 12 bulan, dianalisis menggunakan Generalized Linear Model (GLM) berdasarkan Steel dan Torrie (1995) sebagai berikut:

$$
\mathrm{Y}=\mu+\mathrm{si}+\mathrm{pi}+\mathrm{qi}+\mathrm{e}
$$

keterangan:

$\mathrm{Y}$ = bobot lahir, bobot sapih, dan bobot 12 bulan sapi Bali 
$\mu=$ rataan

si $=$ efek dari jenis kelamin (jantan, betina)

pi $=$ efek dari beranak ke- $(1,2,3)$

qi $=$ efek dari tahun kelahiran $(2008,2009, \ldots, 2013)$

$\mathrm{e}=$ eror

Pendugaan Nilai Pemuliaan (EBV) dihitung dengan menggunakan rumus matematis berdasarkan Hardjosubroto (1994) sebagai berikut :

$$
N P=h^{2}(P-\bar{P})
$$

keterangan :

$\mathrm{NP}=$ Nilai Pemuliaan

$\mathrm{h} 2=$ nilai heritabilitas

$P \quad=$ performans individu

$\overline{P P} \quad=$ rataan performans populasi dimana individu diukur

Pendugaan nilai koefisien regresi dihitung dengan menggunakan rumus matematis berdasarkan Filho et al. (2005) disajikan sebagai berikut:

$$
\mathrm{Y}=\mathrm{a}+\mathrm{bX}
$$

keterangan:

$$
\begin{array}{ll}
\mathrm{Y} & =\mathrm{BL}, \mathrm{BS}, \text { dan } \mathrm{BY} \\
\mathrm{a} & =\text { intersep } \\
\mathrm{X} & =\text { tahun kelahiran } \\
\mathrm{b} & =\text { koefisien regresi }
\end{array}
$$

\section{HASIL DAN PEMBAHASAN}

\section{Parameter Genetik}

Nilai heritabilitas BL, BS, dan BY yang diperoleh pada penelitian ini masing-masing $0.02 \pm 0.08 ; 0.83 \pm 0.18$ dan $0.62 \pm 0.30$ (Tabel 1). Nilai heritabilitas BL pada penelitian ini jauh lebih rendah sedangkan nilai BS dan BY lebih tinggi dibandingkan dengan beberapa penelitian sebelumnya untuk bangsa sapi Bali (Sukmasari et al., 2002; Ardika et al., 2011; Gunawan et al., 2011; Baiduri et al., 2012; Kaswati et al., 2013).Nilai dugaan heritabilitas yang cukup tinggi secara teoritis disebabkan meningkatnya variasi genetik dalam populasi dengan asumsi variasi lingkungan tetap dengan demikian nilai heritabilitas BS dan BY pertambahan bobot badan pra sapih cukup efektif digunakan dalam program seleksi (Karnaen 2008; Baiduri et al., 2012).

Menurut Hardjosubroto (1994) dan Warwick et al. (1995), nilai heritabilitas dikatakan rendah apabila bernilai kurang dari 0.10 ; sedang jika nilainya antara $0.10-0.30$ dan tinggi jika lebih dari 0.30 . Heritabilitas bukan suatu konstanta tetapi hanya berlaku pada populasi tertentu, waktu tertentu

Tabel 1. Nilai heritabilitas dan ripitabilitas bobot lahir (BL), bobot sapih (BS) dan bobot 1 tahun (BY) sapi Bali di BPTU HPT Denpasar

\begin{tabular}{llll}
\hline Uraian & BL & BS & BY \\
\hline Heritabilitas \pm SE & $0,02 \pm 0,08$ & $0,83 \pm 0,18$ & $0,62 \pm 0,30$ \\
Ripitabilitas \pm SE & $0,99 \pm 0,001$ & $0,98 \pm 0,006$ & $0,97 \pm 0,009$ \\
\hline
\end{tabular}

Tabel 2. Korelasi genetik (di bawah diagonal) dan fenotipik (di atas diagonal) bobot lahir (BL), bobot sapih (BS) dan bobot 1 tahun (BY) sapi Bali di BPTU HPT Denpasar

\begin{tabular}{llll}
\hline Sifat & BL & BS & BY \\
\hline BL & & 0,07 & 0,145 \\
BS & 0,034 & & 0,65 \\
BY & 0,094 & 0,719 & \\
\hline
\end{tabular}

dan metode perhitungan tertentu (Pirchner 1969; Falconer \& Mackay, 1996). Keragaman lingkungan, metode analisis dan jumlah sampel yang digunakan dan heritabilitas berubah menurut jenis ternak, sifat, populasi, bangsa, waktu, dan daerah (Warwick et al., 1995; Putra et al., 2014). Beberapa lingkungan dapat menyebabkan ekspresi perbedaan genetik yang lebih besar yang memperbesar keragaman genetik dan heritabilitas (Warwick et al., 1995). Waktu perhitungan dan populasi yang berbeda, akan menyebabkan perbedaan nilai heritabilitas yang diperoleh karena terjadi perubahan komposisi ternak dan ragam genetik yang terdapat di dalam populasi (Hardjosubroto, 1994).

Nilai ripitabilitas pada penelitian ini untuk BL, BS dan BY masing-masing $0.99 \pm 0.001 ; 0.98 \pm 0.006$ dan $0.97 \pm 0.009$. Nilai ripitabilitas BL yang diperoleh pada penelitian ini termasuk kategori yang tinggi $(r>0.30)$. Nilai ripitabilitas yang tinggi menunjukkan bahwa tetua memiliki peluang yang tinggi untuk memiliki anak yang memiliki bobot badan sama seperti pada anak sebelumnya (Putra et al., 2014).

Korelasi genetik untuk sifat pertumbuhan pada penelitian ini bernilai positif, artinya sifat yang satu akan memberikan respon terhadap sifat yang lain. Nilai korelasi genetik dan fenotipik untuk BL dengan BS, BL dengan BY, serta BS dengan BY yaitu $0.070 ; 0.145 ; 0.650$ dan 0.034; 0.094; 0.714 (Tabel 2). Korelasi paling tinggi adalah pada BS dengan BYbaik untuk korelasi genetik maupun fenotipik yang berarti akan memberikan respon seleksi yang tinggi dan dapat dipergunakan sebagai pertimbangan dalam melakukan seleksi. Korelasi genetik merupakan korelasi antara nilai pemuliaan aditif pada dua sifat ternak atau merupakan pengaruh gen-gen aditif terhadap dua sifat atau lebih. Korelasi genetik merupakan hasil aksi gen pleotropik yaitu gen-gen yang mempengaruhi dua sifat atau lebih (Warwick et al., 1995).

\section{Pengaruh Non-Genetik dan Genetik}

Dari sebanyak 573 anak sapi Bali yang lahir di BPTU HPT Denpasar diperoleh estimasi rataan BL, BS dan BY sebagaimana tersaji pada Tabel 3. Rataan BL yang diperoleh pada penelitian ini relatif tidak berbeda dengan BL pada penelitian Gunawan et al. (2011) dan Kaswati et al. (2013) yaitu $18,00 \pm 4,00 \mathrm{~kg}$ dan $17,8 \pm 1,08 \mathrm{~kg}$. Rataan BS dan BY pada penelitian ini relatif lebih rendah dibandingkan hasil penelitian Sukmasari et al. (2002), Praharani (2007); Gunawan et al. (2011), dan Kaswati et al. (2013) yaitu $92,62 \pm 15,85 \mathrm{~kg} ; 90.5 \mathrm{~kg} ; 86,78 \pm 1,95 \mathrm{~kg}$; dan 88,59 $\pm 16,15$ $\mathrm{kg}$ untuk BS serta $140,92 \pm 15,29 \mathrm{~kg} ; 139.5 \mathrm{~kg} ; 144,56 \pm 5,03$ $\mathrm{kg}$; dan $131,12 \pm 25,50 \mathrm{~kg}$ untuk BY. Perbedaan nilai rataan bobot pada penelitian ini dapat disebabkan oleh perbedaan data dan waktu perhitungan, selain itu adanya perbedaan 
Tabel 3. Rataan dan simpangan baku bobot lahir (BL), bobot sapih (BS) dan bobot 1 tahun (BY) sapi Bali di BPTU HPT Denpasar

\begin{tabular}{|c|c|c|c|}
\hline \multirow[t]{2}{*}{ Uraian } & \multicolumn{3}{|c|}{ Sifat $(\mathrm{kg})$} \\
\hline & $\mathrm{BL}(\mathrm{n})$ & $\mathrm{BS}(\mathrm{n})$ & $\mathrm{BY}(\mathrm{n})$ \\
\hline Total N (ekor) & 573 & 541 & 523 \\
\hline Rataan & $17,91 \pm 1,26(573)$ & $85,06 \pm 16,55(541)$ & $117,56 \pm 19,40(523)$ \\
\hline \multicolumn{4}{|l|}{ Jenis Kelamin } \\
\hline Jantan & $18,04 \pm 1,38$ A $(280)$ & $87.20 \pm 17.89$ A (264) & $124.66 \pm 20.32 \mathrm{~A}(255)$ \\
\hline Betina & $17,79 \pm 1,14$ B (293) & $83.02 \pm 14.91$ B (277) & $110.81 \pm 15.78$ B (268) \\
\hline \multicolumn{4}{|l|}{ Paritas } \\
\hline 1 & $17,69 \pm 1,22 \mathrm{AB}(166)$ & $84.31 \pm 16.79$ A (153) & $115.86 \pm 19.65$ A (147) \\
\hline 2 & $17,83 \pm 1,32 \mathrm{AB}(113)$ & $86.65 \pm 16.48$ A (106) & $118.46 \pm 19.17 \mathrm{~A}(103)$ \\
\hline 3 & $18,02 \pm 1,21 \mathrm{AB}(96)$ & $84.02 \pm 15.88$ A (92) & $117.78 \pm 18.48$ A (89) \\
\hline 4 & $18,07 \pm 1,34 \mathrm{AB}(77)$ & $89.61 \pm 18.08$ A (75) & $120.68 \pm 18.42 \mathrm{~A}(74)$ \\
\hline 5 & $18,33 \pm 1,38 \mathrm{BC}(57)$ & $81.79 \pm 17.69$ A (52) & $118.49 \pm 26.77$ A (49) \\
\hline 6 & $18,03 \pm 1,12 \mathrm{AB}(37)$ & $84.00 \pm 15.21 \mathrm{~A} \mathrm{(36)}$ & $115.59 \pm 14.76$ A (34) \\
\hline 7 & $17,75 \pm 0,91 \mathrm{AB}(20)$ & $81.30 \pm 10.18 \mathrm{~A}(20)$ & $115.10 \pm 15.29$ A (20) \\
\hline 8 & $17,68 \pm 1,37 \mathrm{AB}(6)$ & $83.83 \pm 9.68 \mathrm{~A}(6)$ & $114.33 \pm 4.68 \mathrm{~A}(6)$ \\
\hline 9 & $18,00 \pm 0,00 \mathrm{AB}(1)$ & $77.00 \pm 0.00 \mathrm{~A}(1)$ & $117.00 \pm 0.00 \mathrm{~A}(1)$ \\
\hline \multicolumn{4}{|l|}{ Tahun } \\
\hline 2008 & $18,91 \pm 1,23$ A (99) & $91.48 \pm 19.15$ AB (85) & $121.80 \pm 25.27 \mathrm{~A}(85)$ \\
\hline 2009 & $18,29 \pm 1,26 \mathrm{~B}(100)$ & $89.78 \pm 15.68$ AB (90) & $122.57 \pm 18.09$ A (88) \\
\hline 2010 & $18,30 \pm 1,43$ B (89) & $73.18 \pm 17.46$ C (84) & $115.96 \pm 30.99 \mathrm{AB}(84)$ \\
\hline 2011 & $17,57 \pm 1,03 \mathrm{C}(100)$ & $92.32 \pm 12.21 \mathrm{~A}(98)$ & $115.33 \pm 9.42 \mathrm{AB}(97)$ \\
\hline 2012 & $17,25 \pm 0,75$ CD (99) & 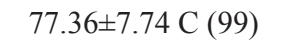 & 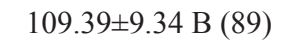 \\
\hline 2013 & $17,08 \pm 0,64 \mathrm{D}(86)$ & $85.99 \pm 15.88$ B (85) & $121.03 \pm 9.44 \mathrm{~A}(80)$ \\
\hline
\end{tabular}

Keterangan : Superskrip berbeda pada kolom yang sama menunjukkan berbeda nyata $(\mathrm{P}<0.01)$. $\mathrm{n}=$ jumlah ternak.

nutrien pakan karena perubahan iklim, musim dan manajemen pemeliharaan (Speidel et al., 2007; Frizzaset al., 2009).

Hasil estimasi pada penelitian ini untuk jenis kelamin tidak berpengaruh terhadap $\mathrm{BL}(\mathrm{P}>0.01)$ namun berpengaruh terhadap $\mathrm{BS}$ dan $\mathrm{BY}(\mathrm{P}<0.01)$. Gunawan et al. (2011) menjelaskan bahwa jenis kelamin memberikan efek yang signifikan pada bobot sapih dan tingkat pertumbuhan, semakin nampak pada umur setelah pubertas. Ngadiyono (1995) serta Liza dan Elizabet (2006) menjelaskan bahwa jenis kelamin dapat menyebabkan perbedaan laju pertumbuhan danakan lebih besar sesuai dengan bertambahnya umur. Berat badan untuk sapi jantan lebih tinggi dikarenakan oleh hormon ternak jantan dan produk susu induk lebih banyak pada ternak yang menyusui anak jantan. Hormon testoteron adalah salah satu dari steroid androgen yang dihasilkan oleh testesterlibat dalam pengaturan pertumbuhan dan terutama bertanggungjawab atas perbedaan komposisi tubuh antara jenis kelamin jantan dan betina (Soeparno, 1992; Cox et al., 2009; Lawrence et al., 2012).Hal tersebut juga menjelaskan rataan BL, BS dan BY untuk jantan dan betina pada penelitian ini berbeda. Rataan sapi Bali jantan lebih besar dibandingkan dengan rataan sapi Bali betina untuk ketiga sifat yang diamati (Tabel 1).

Paritas berpengaruh terhadap BL $(\mathrm{P}<0.01)$ namun tidak berpengaruh terhadap BS dan BY $(\mathrm{P}>0.01)$. Produksi susu dan kemampuan menyusui pada induk tua dan muda berbeda, dimana produksi susu pada induk tua lebih banyak daripada yang muda sehingga anak-anak dari induk tua lebih berat dibanding induk muda tetapi akan menurun seiring dengan meningkatnya umur induk (Gunawan et al., 2011). Hal ini memberikan gambaran bahwa kondisi badan induk sebagai salah satu faktor lingkungan tempat anak dilahirkan dengan bertambah baiknya kondisi badan induk, akan mampu mensuplai kebutuhan air susu secara optimal selama menyusui (Pasambeet al., 2000 dan Gunawan et al., 2011).

Tahun kelahiran berpengaruh terhadap ketiga sifat yang diukur $(\mathrm{p}<0.01)$. Pelaksanaan pemuliaan bergantung beberapa faktor yaitu iklim dan pakan, kesehatan, manajemen dan kondisi produksi lainnya. Setiap perlakuannya harus disesuaikan dengan kondisi biologis tertentu, sosial-ekonomi dan logistik tertentu. Karena interval generasi ternak sapi cukup panjang, sedangkan dampak dari program pemuliaan tidak dirasakan dalam waktu dekat, dimungkinkan dalam jangka waktu tersebut persyaratan yang dibutuhkan juga berbeda (Jain\&Muladno, 2009; Madalena et al., 2002).

\section{Pola Genetik dan Fenotipik}

Pola genetik dan fenotipik BL, BS, dan BY pada penelitian ini sebagaimana disajikan pada Tabel 4 . Persamaan regresi yang diperoleh untuk nilai pemuliaan (EBV)semua sifat yang diamati serta tren fenotipik BS dan 
Tabel 4. Tren genetik danfenotipiksifat pertumbuhan sapi Bali di BPTU HPT Denpasar

\begin{tabular}{llc}
\hline & Persamaan regresi & R2 \\
\hline Tren genetik & EBV BL $=0,00034-0,000000 \mathrm{x}$ & 0,21 \\
& EBV BS $=0,825-0,000411 \mathrm{x}$ & 20,4 \\
& $\mathrm{EBV} \mathrm{BY}=0,51-0,000253 \mathrm{x}$ & 5 \\
Tren fenotipik & $\mathrm{BL}=19,20-0,3710 \mathrm{x}$ & 95,1 \\
& $\mathrm{BS}=89,58-1,302 \mathrm{x}$ & 9,4 \\
& $\mathrm{BY}=122,1-1,258 \mathrm{x}$ & 21,4 \\
\hline
\end{tabular}

Keterangan : R2 adalah angka determinasi

BY tidak signifikan $(\mathrm{P}>0.01)$ dengan koefisien determinan $\left(\mathrm{R}^{2}\right)$ rendah. Sebaliknya, persamaan regresi untuk pola fenotipik BL signifikan $(\mathrm{P}<0.01)$ dengan koefisien $\mathrm{R}^{2}$ tinggi sehingga bisa dikatakan untuk tren $\mathrm{BL}$ sapi Bali menurun. Rataan BL menurun $(\mathrm{P}<0.01)$ tiap tahunnya dari berat $18.91 \pm 1.23 \mathrm{~kg}$ pada 2008 menjadi $17.08 \pm 0.64 \mathrm{~kg}$ pada tahun 2013.

Rataan EBV BL dari tahun 2008-2013 tidak berfluktuasi seperti yang diperlihatkan EBV BS dan BY (Gambar 1).Rataa EBV BS dan BY sangat berfluktuasi dari tahun 2008-2013, naik turun setiap tahunnya. Rataan sifat fenotipik yang diukur pada penelitian ini tidak sangat berfluktuasi sebagaimana EBV BS dan BY (Gambar 2). Rataan BS dan BY memperlihatkan penurunan daritahun 2008-2010, namun baik rataan BS dan BY mengalami kenaikan kembali pada tahun 2013 dengan nilai rataannya tidak berbeda nyata dengan rataan pada tahun 2008 (Tabel 1). Tahun kelahiran berpengaruh terhadap penampilan dapat disebabkan karenafluktuasi ketersediaan pakan dari tahun ke tahun atau karenaketidakstabilan praktek manajemen yang terkait dengan cara pemberian pakan, manajemen kesehatandan perubahan faktor iklim serta pengaruh induk yang tidak dapat diabaikan (Gunawan et al., 2011; Ali et al., 2015). Ketersediaan pakan di Pusat Pembibitan bervariasi dari rumput padang penggembalaan, hijauan pakan ternak yang ditanam, sampai dengan limbah hasil pertanian yang memerlukan suplemen pakan baik itu mineral, protein dan pakan sumber energi yang mempengaruhi baik itu reproduksi maupun produksi ternak (Gunawan et al., 2011).

Estimasi kemajuan genetik yang dicapai oleh program pemuliaan diperlukan untuk menggambarkan

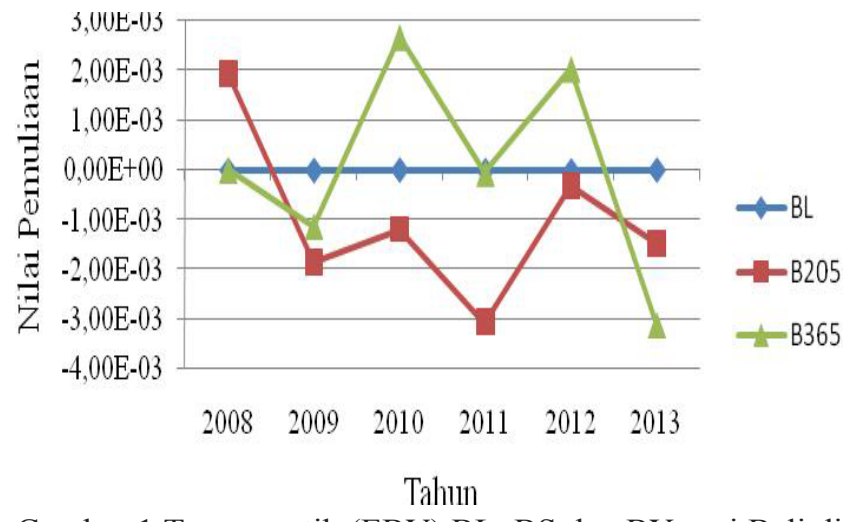

Gambar 1 Tren genetik (EBV) BL, BS dan BY sapi Bali di BPTU HPT Denapasar tahun 2008 -2013

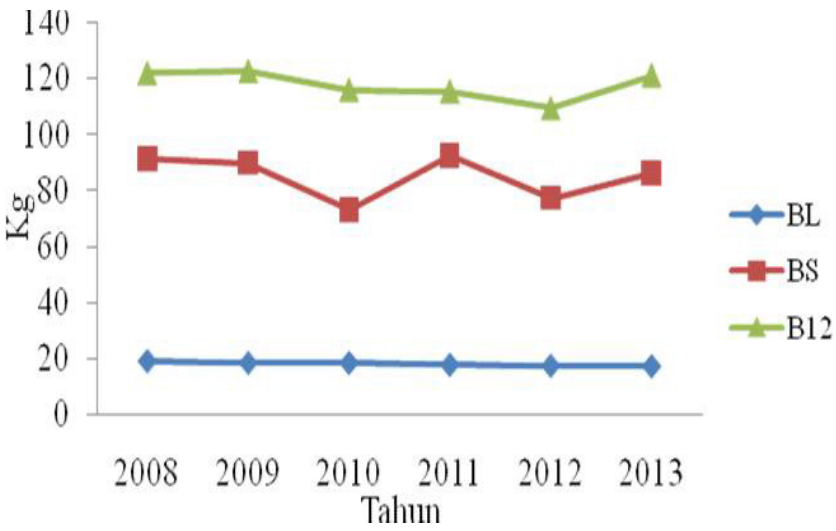

Gambar 2 Tren fenotipik rataan BL, BS dan BY sapi Bali di BPTU HPT Denapasar tahun 2008 -2013

perubahan kemajuan genetik, untuk menilai manfaat program dan mengetahui serta melakukan penyesuaian yang diperlukan (Filho et al.,2005). Perubahan genetik biasa bersifat permanen oleh sebab itu melalui program pemuliaan diharapkan mampu mencegah perubahan genetik yang bersifat negatif atau merugikan. Pelaksanaan dari program pemuliaan memerlukan waktu relatif lama dengan pemanfaatan sumberdaya yang ada secara optimal (Nikimbugwe, 2005). Menurut Lasley (1978) progeny test pada sapi memakan waktu lama, karena jarak generasi anak dan generasi orang tua (interval generasi) sekitar 4-6 tahun.

Pemuliaan dengan skemaintiterbukamengharuskan program pemuliaan yang baik tidak hanya dilakukan diinti melainkan juga diplasma karena potensi genetik yang tidak baik di plasma akan memberikan akibat negatif kepada kemajuan genetik di inti. Seleksi yang dilaksanakan selama ini mempergunakan kriteria fenotipik perlu dikaji kembali karena keunggulan fenotipik yang diperoleh belum tentu mencerminkan merupakan keunggulan genetis ternak. Untuk itu perlu dilakukan pendampingan kelompok plasma paling tidak selama 5 (lima) tahun untuk dapat dilakukan seleksi ternak berdasarkan EBV ternak. Selanjutnya kriteria seleksi yang dipergunakan dapat berupa kriteria yang ditetapkan oleh BPTU HPT Denpasar bukan berdasarkan SNI..

\section{KESIMPULAN}

Nilai heritabilitas BS dan BY pada sapi Bali di BPTU HPT Denpasar termasuk kategoritinggi dan korelasi antar kedua sifat tersebut bernilai positif dengan nilai terbesar sehingga dapat dilaksanakan seleksi pada saat bobot sapih. Tren genetik untuk BL, BS dan BY berfluktuasi, sedangkan tren fenotipik relatif konstant. Namun demikian pada tren fenotipik BL cenderung menurun. Hal tersebut memberikan peringatan akan program pemuliaan yang dilaksanakan untuk dapat dievaluasi.

\section{UCAPAN TERIMAKASIH}

Penulis mengucapkan terimakasih kepada Direktorat Jenderal Peternakan dan Kesehatan Hewan atas Beasiswa Pendidikan S2 yang diberikan serta BPTU HPT Denpasar atas kerjasama yang diberikan. 


\section{DAFTAR PUSTAKA}

Ali IE, IA Ishaq, FH Ibrahim, A Magzoob, MA Ahmed. 2015. Impact of genetic and non-genetic factors on birth weight of crossbred red angus and simmental with local cattle. American Journal of Agricultural Science. 2(3): 80-84.

Ardika N, RR Indrawati, J Djegho. 2011. Parameter genetik sifat produksi dan reproduksi sapi bali di daerah Bali. Majalah Ilmiah Peternakan. Vol 14, No 1.

Assan N. 2012. Genetic improvement and utilization of indigenous cattle breeds for beef production in Zimbabwe: past, present and future prospects. Scientific Journal of Agricultural 1(1) 1-13.

Baiduri AA, Sumadi, N Ngadiyono. 2012. Pendugaan nilai heritabilitas ukuran tubuh pada umur sapih dan umur setahun sapi bali di balai pembibitan ternak unggul sapi bali, Jembrana, Bali. Buletin Peternakan Vol. 36(1): $1-4$.

BPTU Sapi Bali. 2012. Roadmap BPTU Sapi Bali. BPTU Sapi Bali-Bali.

Becker WA. 1992. Manual of quantitative genetics, $5^{\text {th }}$ ed. Academic Enterprise., USA.

BIF (Beef Improvement Federation). 2002. Guidelines for Uniform Beef Improvement Programs. $8^{\text {th }}$ ed.Kansas State Univ. Kansas.

Cox RM, DS Stenquis, R Calsbeek. 2009. Testosterone, growth and the evolution of sexual size dimorphism. $\mathrm{J}$ Evol Biol. 22(8):1586-1598.

Falconer DS, TFC Mackay. 1996. Intoduction to quantitative genetics. FourthEdition. Logman Group Ltd, CM 202 JE, England.

Filho RAT, RA Torres, PS Lopes, CS Pereira, RF Euclydes, CV Araujo, MA Silva. 2005. Genetic trends in the performance and reproductive traits of pigs. Genet. Mol. Biol. 28:97-102.

Frizzas OG, DA Grossi, ME Buzanskas, CCP Paz, LAF Bezerra, RB Lo^ bo, JA Oliveira, DP Munari. 2009. Heritability estimates and genetic correlations for body weight and scrotal circumference adjusted to 12 and 18 months of age for male Nellore cattle. Animal, 2009, 3:3, pp 347-351.

Gunawan A, R Sari, Jakaria. 2012. Estimates of genetic and phenotypic trends of growth traits in Bali cattle. Media Peternakan, Agustus 2012, hlm. 85-90.

Gunawan A, Jakaria. 2011. Genetic and non-genetics effect on birth, weaning, and yearling weight of bali cattle. Media Peternakan, Agustus 2011, hlm. 93-98.

Gunawan A, R Sari, Y Parwoto, MJ Uddin. 2011. Non genetic factors effect on reproductive performance and preweaning mortality from artificially and naturally bred in bali cattle. J.Indonesian Trop.Anim.Agric. $36(2): 83-90$.

Hammoud MH, SZ El-Zarkounyl, EZM Oudah. 2010. Effect of Sire, age at first calving, season, and year of calving and paritas on reproductive performance of Frisien cows under semiarid conditions in Egypt. Arch. Zootech. 13: 60-82.

Hardjosubroto W. 1994. Aplikasi Pemuliabiakan Ternak di Lapangan. Jakarta: PT Gramedia Widiasarana Indonesia.

Harris DL, S Newman. 1994. Breeding for profit: synergism between genetic improvement and livestock production (a review). Journal of Animal Science, 72:2178-2200.

Mueller JP. 1984. Single and two-stage selection on difference indices in open nucleus breeding system. Genet. Sel. Evlo., 1984, 16 (1), 103-120.

Jain AK, M Muladno. 2009. Selection criteria and breeding objectives in improvement of productivity of cattle and buffaloes. Selection And Breeding Of Cattle In Asia: Strategies And Criteria For Improved Breeding Iaea, Vienna, 2009. P. 11.

Johan A, M. van Arendonk. 2011. The role of reproductive technologies in breeding schemes for livestock population in developing countries. Livestock Science 136. p 29-37.

Karnaen. 2008. Pendugaan heritabilitas, korelasi genetik dan korelasi fenotipik sifat bobot badan pada sapi madura. J.Indon.Trop.Anim.Agric. 33 [3]: 191-196.

Kaswati, Sumadi, N Ngadiono. 2013. Estimasi nilai heritabilitas berat lahir, sapih, dan umur satu tahun pada sapi Bali di Balai Pembibitan Ternak Unggul Sapi Bali. Buletin Peternakan Vol. 37(2): 74-78.

Lasley FJ. 1978. Genetiks of livestock improvement. Prentice Hall. Inc. Englewood Cliffs. USA.

Lawrence TLJ, VR Fowler, JE Novakofski. 2012. Growth of Farm Animal. $3^{\text {rd }}$ edition. CABI. USA.

Praharani L, E Juarini. 2006. Evaluasi Keragaan Berat Badan Sapi Bali Umur 190 Hari dan 350 Hari. Lokakarya Nasional Pengelolaan dan Perlindungan Sumber Daya Genetik di Indonesia: Manfaat Ekonomi untuk Mewujudkan Ketahanan Nasional. Puslitbangnak.

Madalena FE, K Agyemang, RC Cardellino, GL Jain. 2002. Genetic improvement in medium-to low-input system of animal production. Experiences to Date. $7^{\text {th }}$ World Congress on Genetics Applied to Livestock Production, August 19-23.

Meyer K. 1992. Variance component due to direct and maternal effect for growth traits of Australian beef cattle. Livest. Prod. Sci. 31:179-204.

Mizeck GG, Chagunda \& BA Wollny. 2003. A concept note on interactive processes and technologies to conserve indigenous farm animal genetic resources in malawi. Proc. of the Fao Workshop "community-based Management of Animal Genetic Resources”, 2003, p. 143-146.

Ngadiyono P. 1995. Pertumbuhan serta sifat-sifat karkas dan daging sapi Sumba Ongole, Brahman Cross dan Australian Comercial Cross yang dipeliahara secara intensif pada berbagai bobot potong. Thesis. Fakultas Peternakan Institut Pertanian Bogor. Bogor.

Nikimbugwe DHN. 2005. Open nucleus cattle breeding programme in the lake Victoria Crescent Region of Uganda. Dissertation. Department of Sustainable Agricultural Systems, University of Natural Resources and Applied Life Sciences, Vienna, Austria.

Tada O. 2012. Breeding objectives for in-situ conservation of indigenous Nguni cattle under low-input production 
systems in South Africa. Dissertation. Department of Livestock and Pasture Science, Faculty of Science and Agriculture, University of Fort Hare. Alice, South Africa.

Pasambe D, M Sariubang, A Nurhayu, S Bahar, Chalidjah. 2000. Pengaruh perbaikan pakan pada induk sapi Bali terhadap pertambahan bobot badan pedet yang sedang menyusui. Instalasi Penelitian dan Pengkajian Teknologi Pertanian. Gowa.

Pirchner F. 1969. Population genetics in animal breeding. W. H. Freeman and Company, San Francisco.

Putra WPB, Sumadi \& T Hartatik. 2014. Estimasi nilai pemuliaan dan most probable producing ability sifat produksi sapi aceh di kecamatan Indrapuri provinsi Aceh. Buletin Peternakan Vol. 38(1): 1-7.

Putra WPB, Sumadi, T Hartatik \& H Saumar. 2014. Seleksi pada sapi aceh berdasarkan metode indeks seleksi dan nilai pemuliaan. Jurnal Peternakan Sriwijaya. Vol. 4(1) : 1-10.

Rege JEO, K Marshall, A Notenbaert, JMK Ojango, AM Okeyo. 2011. Pro-poor animal improvement and breeding - what can science do. Livestock Science 136. p 15-26.

Soeparno. 1992 . Ilmu Teknologi Daging . Gajah Mada University Press. Yogyakarta.

Speidel SE, R Erns, DJ Garrick. 2007. Weaning weight inheritance in environments classified by maternal body weight change. J Anim Sci. 85:610-617.

Steel RGD, JH Torrie. 1995. Prinsip dan Prosedur Statistika. Penerjemah: Sumantri B. Ed ke-4. Jakarta: Gramedia.

Sukmasari AH, RR Noor, H Martojo, C Talib. 2002. The estimation of breeding values and genetics trends of body weight in Bali cattle improvement project. Hayati. 9: 109-113.

Warwick JE, JM Astuti, W Hardjosubroto. 1995. Pemuliaan Ternak. Gadjah Mada University Press. Yogyakarta. 